Abstracta Iranica Abstracta Iranica

Revue bibliographique pour le domaine irano-aryen

Volume 29 | 2008

Comptes rendus des publications de 2006

\title{
Cuneiform in Canaan. Cuneiform Sources from the Land of Israel in Ancient Times. Jerusalem 2006. pp. 239, 15 pl. de copies et $17 \mathrm{pl}$. de photos.
}

\section{Astrid Nunn}

\section{(2) OpenEdition}

1 Journals

Édition électronique

URL : http://journals.openedition.org/abstractairanica/25962

DOI : 10.4000/abstractairanica.25962

ISSN : 1961-960X

Éditeur :

CNRS (UMR 7528 Mondes iraniens et indiens), Éditions de l'IFRI

Édition imprimée

Date de publication : 15 mai 2008

ISSN : 0240-8910

Référence électronique

Astrid Nunn, "Cuneiform in Canaan. Cuneiform Sources from the Land of Israel in Ancient Times.

Jerusalem 2006. pp. 239, 15 pl. de copies et 17 pl. de photos. », Abstracta Iranica [En ligne], Volume

29 | 2008, document 77, mis en ligne le 15 septembre 2008, consulté le 26 septembre 2020. URL

http://journals.openedition.org/abstractairanica/25962 ; DOI : https://doi.org/10.4000/

abstractairanica.25962

Ce document a été généré automatiquement le 26 septembre 2020.

Tous droits réservés 
Cuneiform in Canaan. Cuneiform Sources from the Land of Israel in Ancient Times. Jerusalem 2006. pp. 239, $15 \mathrm{pl}$. de copies et $17 \mathrm{pl}$. de photos.

\author{
Astrid Nunn
}

1 Les sources écrites sont relativement rares en Israël/Palestine. Raison de plus pour donner un aperçu clair de tout ce qui a été trouvé jusqu'à présent. Des 91 textes provenant de 28 sites, cinq seulement sont datés avec certitude de l'époque perse : une tablette économique inédite de Mikhmoret, trois monnaies de Samarie et un fragment de vase avec le nom d'un Artaxerxès trouvé dans les fouilles anciennes de Sepphoris.

\title{
INDEX
}

Thèmes : 3.2.2. Pré-Achéménides et Achéménides

\section{AUTEURS}

ASTRID NUNN

Université de Munich 